\title{
TANGGUNG JAWAB PERUSAHAAN DAN KARYAWAN DALAM ISLAM
}

\begin{abstract}
Ain Rahmi
ABSTRAK

Generasi masa kini harus memanfaatkan seefisien mungkin sumber daya alam yang tersedia sesuai dengan kebutuhan yang optimal. Keberlanjutan dapat dilihat dari beberapa dimensi yang merupakan dimensi yang saling berkaitan dengan keberlanjutan itu sendiri, antara lain; manusia, sosial, lingkungan, dan ekonomi. Bisnis tidak terlepas dari etika dikarenakan pertama, bisnis tidak bebas nilai. Kedua, bisnis merupakan bagian dari sistem sosial. Ketiga, aplikasi etika bisnis identik dengan pengelolaan bisnis secara professional. Perkembangan bisnis atau perusahaan, baik sebagai akibat maupun sebagai salah satu sebab perkembangan politik, ekonomi sosial maupun teknologi serta aspek lingkungan di sekitarnya, jika selama ia berinteraksi dan menghasilkan barang dan jasa bagi masyarakat yang membutuhkannya, maka bisnis atau perusahaan itu harus menyadari akan tanggung jawab terhadap lingkungannya, khususnya tanggung jawab sosial dengan segala aspeknya. Dalam Islam sendiri sangat menjunjung tinggi akan tanggung jawab sosial baik itu untuk perusahaan dan para karyawan. Dalam al-Qur'an juga dijelaskan bahwa setiap kita (manusia) akan diminta pertanggung jawaban kelak di akhirat atas apa yang telah diperbuat selama di dunia ini, begitu juga dalam sebuah hadits yang mengatakan bahwa setiap orang yang diberikan beban tanggung jawab haruslah sesuai dengan keahlian yang dimiliki dan menjunjung tinggi tanggung jawab kepada perusahaan yang telah memberikan kepercayaan bagi para karyawannya dalam menjalankan bisnis.
\end{abstract}

Keyword : Perusahaan, Karyawan, Islam

\section{PENDAHULUAN}

Dewasa ini tidak cukup bagi perusahaan hanya memfokuskan diri pada pertumbuhan ekonomi semata, akan tetapi dibutuhkan sebuah paradigma baru di bidang bisnis yaitu, pembangunan yang berkelanjutan maksudnya adalah suatu upaya untuk memenuhi kebutuhan masa kini tanpa mengurangi kemampuan dan kesempatan generasi berikut untuk dapat memenuhi kebutuhannya. Generasi masa kini harus memanfaatkan seefisien mungkin sumber daya alam yang tersedia sesuai dengan kebutuhan yang optimal. Keberlanjutan dapat dilihat dari beberapa dimensi yang merupakan dimensi yang saling berkaitan dengan keberlanjutan itu sendiri, antara lain; manusia, sosial, lingkungan, dan ekonomi. Keberlanjutan di bidang manusia erat kaitannya dengan pemeliharaan kualitas sumber daya manusia secara individual seperti, kesehatan, pendidikan, keterampilan, kepemimpinan, dan juga pengetahuannya.

Keberlanjutan di bidang sosial adalah suatu bentuk pemeliharaan manusia secara kolektif, melalui partisipasi secara sistematis semua komponen masyarakat, baik dalam bentuk kerjasama sesama komunitas, hubungan antarkelompok dalam masyarakat, pertukaran, toleransi, etika, pertemanan, kejujuran, yang terwujud pada aturan-aturan hukum dan disiplin menuju ke arah kebersamaan dan kesetaraan. Keberlanjutan di bidang lingkungan hidup dapat diartikan sebagai kepedulian manusia akan kelestarian sumber daya alam yang sangat terbatas, manusia harus mengoptimalkan antara kebutuhan dan sumber daya yang ada 
bagi generasi berikutnya. Keberlanjutan di bidang ekonomi maksudnya adalah penggunaan sumber daya modal secara efisien dan menjamin produktivitas investasi dan pertumbuhan yang wajar dari seluruh sektor.

Pembangunan yang berkelanjutan akan terwujud jika semua pihak yang memiliki kekuasaan, kepentingan dan mempunyai pengaruh terhadap jalannya perusahaan baik yang berada pada sisi dalam perusahaan maupun pada sisi luar perusahaan bekerja sama dan mendukung program-program perusahaan. Bentuk-bentuk stakeholder dan macamnya dapat terlihat dalam tabel berikut ini.

\begin{tabular}{|c|c|}
\hline $\begin{array}{l}\text { A. Di dalam perusahaan terdiri dari } \\
\text { Pemilik saham/investor } \\
\text { Pensiunan Karyawan } \\
\text { Pemegang dana } \\
\text { Manager penyandang dana }\end{array}$ & $\begin{array}{l}\text { B. Karyawan terdiri dari : } \\
\text { Karyawan Baru } \\
\text { Karyawan Lama } \\
\text { Karyawan Minoritas } \\
\text { Pensiunan } \\
\text { Karyawan dengan Keluarganya } \\
\text { Perusahaan }\end{array}$ \\
\hline $\begin{array}{l}\text { C. Costumer terdiri dari : } \\
\text { Individu Pembeli } \\
\text { Pasar Tradisional } \\
\text { Lembaga Konsumen } \\
\text { Asosiasi konsumen }\end{array}$ & $\begin{array}{l}\text { D. Korporat terdiri dari : } \\
\text { Pemasok (Supplier) } \\
\text { Competitor } \\
\text { Asosiasi Korprorat } \\
\text { Asosiasi Keuangan }\end{array}$ \\
\hline $\begin{array}{l}\text { E. Komuniti terdiri dari : } \\
\text { Penduduk yang tinggal dekat dengan } \\
\text { usaha } \\
\text { Asosiasi-asosiasi Masyarakat } \\
\text { (RT/RW, Karang Taruna, Perkumpulan } \\
\text { Petani, dsb.) } \\
\text { Organisasi Amal } \\
\text { Sekolah dan Universitas } \\
\text { Kelompok-kelompok Kepentingan }\end{array}$ & $\begin{array}{l}\text { F. Media Massa terdiri dari : } \\
\text { Wartawan } \\
\text { Kolumnis }\end{array}$ \\
\hline $\begin{array}{l}\text { G. Lingkungan terdiri dari : } \\
\text { Lingkungan alam } \\
\text { Spesies bukan manusia } \\
\text { Generasi mendatang } \\
\text { Ilmuan } \\
\text { Kelompok-kelompok lingkungan }\end{array}$ & $\begin{array}{l}\text { H. Pemerintahan terdiri dari : } \\
\text { Pengambil keputusan } \\
\text { (DPRD, DPR) } \\
\text { Pemerintah Daerah }\end{array}$ \\
\hline
\end{tabular}

Salah satu cara mengakomodir stakeholder terkait adalah dengan cara menjalankan program Tanggung jawab Sosial Perusahaan yang merupakan komitmen usaha untuk bertindak secara etis, beroperasi secara legal dan berkontribusi untuk peningkatan ekonomi bersamaan dengan peningkatan kualitas hidup karyawan dan keluarganya, komuniti lokal dan masyarakat secara luas melalui program yang berkesinambungan yang melibatkan semua stakeholder terkait, berikut akan digambarkan model kerja sama antar-stakeholder. ${ }^{1}$ Dari gambar tersebut terlihat interaksi antara perusahaan dan stakeholder lainnya melalui program tanggung jawab sosial akan memberikan manfaat dan keuntungan bersama bagi perusahaan dan bagi stakeholder lainnya.

1 Dikutip dalam Faisal Badroen. Etika Bisnis dalam Islam. (Jakarta : Kencana Prenada Media Group, 2007). hlm. 190 , Arief Budimanta,dkk, Corporate Social Responsibility, ISCD, Jakarta, 2004, hlm. 108. 


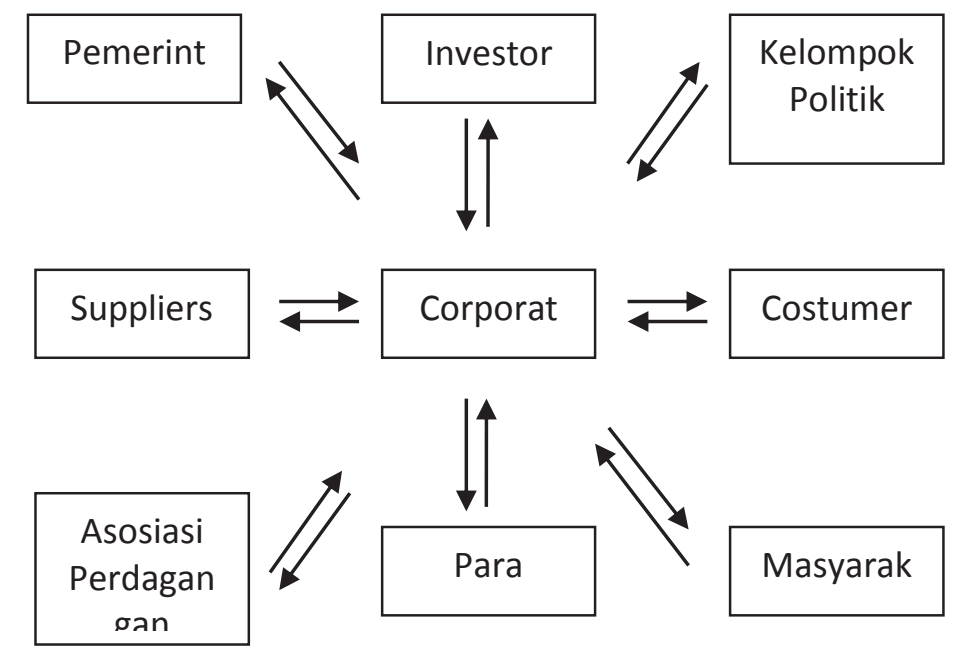

Wujud program Corporate Social Responsibility tidak hanya berupa bantuan-bantuan yang sifatnya jangka pendek seperti, bantuan pembangun jalan, bantuan pembangunan sarana ibadah, atau bantuan perayaan hari-hari besar nasional, akan tetapi berupa program pemberdayaan masyarakat yang dalam jangka waktu yang panjang dapat memberikan perubahan kesejahteraan masyarakat seperti, pembuatan koperasi simpan pinjam, pemberian beasiswa, program orang tua asuh bagi usaha mikro kecil dan menengah (UMKM) dan lain sebagainya. Pelaksanaan program tanggung jawab sosial perusahaan akan memberikan dampak positif tidak hanya bagi operasional perusahaan, akan tetapi juga bagi kelangsungan eksistensi perusahaan untuk jangka panjang, keuntungan yang dapat diraih melalui program ini antara lain; dapat mengurangi biaya, mengurangi risiko, membentuk reputasi, membangun modal sosial, dan meningkatkan akses pasar lebih luas. Sebagai contoh kasus PT. Freeport Indonesia sebelum menjalankan program sustainable development PT Freeport mengalami banyak kendala, baik dalam segi operasional perusahaan seperti, penjarahan, gangguan keamanan dan sorotan tajam dari berbagai kalangan seperti; wakil-wakil rakyat pemerintahan daerah, lembaga-lembaga swadaya masyarakat, maupun dari segi return of investment berapa juta dolar pemasukan yang seharusnya didapat hilang dengan sia-sia karena gangguan-gangguan tersebut.

Menyadari hal tersebut selanjutnya PT Freeport Indonesia mulai memerhatikan stakeholder lain seperti keluar; mengucurkan dana satu persen dari keuntungannya antara 15-20 juta dollar untuk tujuh suku Irian di sekitar Timika, menjadi pembayar pajak terbesar pada urutan pertama setelah sebelumnya berada pada urutan ke-52, dan kedalam membangun sarana ibadah berupa Masjid senilai Rp 5,2 miliar $^{2}$ untuk para karyawan yang beragama Islam setelah sebelumnya kurang memerhatikan aspek pengembangan spiritual karyawannya. Semua yang dilakukan perusahaan lambat laun membuahkan hasil yang dapat mengurangi kendala-kendala perusahaan yang tersebut di atas. Tanggung jawab sosial perusahaan yang diimplementasikan oleh perusahaan di atas adalah bagian dari etika kerja yang sangat dijunjung tinggi oleh nilai-nilai agama. Lebih dari itu, etika kerja juga sangat terkait erat dengan kepuasan kerja (job satisfaction) dan komitmen perusahaan yang dapat meningkatkan produktivitas efesiensi. ${ }^{3}$

2 Dikutip dalam Faisal Badroen. Op.cit. hlm. 192. Amien Rais, Refleksi Amien Rais dari Persoalan Semut sampai Gajah, Gema insane Press, Jakarta, 1997, hlm. 29-30.

3 Badroen, Faisal. 2007. Etika Bisnis dalam Islam. Jakarta : Kencana Prenada Media Group, hlm.192. 


\section{PEMBAHASAN}

\section{Dimensi Aksiologis Pertanggungjawaban Amal Manusia.}

Aksiologis Merupakan ilmu pengetahuan yang menyelidiki hakikat nilai pada umumnya dari sudut pandang kefilsafatan. Ia mempertanyakan kegunaan atau manfaat sesuatu. Dimensi aksiologis biasanya digambarkan dengan pertanyaan untuk apa? Pada konteks bahasan ini, dimensi aksiologis pertanggung jawaban amal manusia mempunyai pengertian, untuk apa dan kenapa manusia harus mempertanggung jawabkan amal perbuatannya. Sebagai bagian tak terpisah dari amal perbuatan, untuk apa bisnis dilakukan dan mengapa harus mempertanggung jawabkan perbuatannya. Sebagai bagian tak terpisah dari amal perbuatan, untuk apa bisnis dilakukan dan mengapa harus ada pertanggung jawaban bisnis. Untuk menjawab persoalan tersebut, terlebih dahulu perlu dibahas siapa manusia dan jati dirinya serta bagaimana kebebasan dan kehendak bebas yang dipunyai oleh manusia. Hal ini dimaksudkan untuk memahami kedirian dan kehendak manusia dalam hubungan dengan amal perbuatan yang harus dipertanggung jawabkan sebagai individual dan secara sosial, baik dihadapan masyarakat, negara dan Tuhan.

Secara filosofis, pandangan tentang siapa manusia mempunyai keberagaman. Menurut Plato manusia adalah jiwa atau pribadinya. Jiwa lebih dahulu dan utama dari pada badannya. Pendapat ini ditentang oleh Thomas Aquinas yang menyatakan bahwa manusia sebagai pribadi adalah mahluk individual yang dianugrahi oleh kodrat rasional. Sementara Jhon Stuart Mill menganggap bahwa pribadi adalah manusia individu yang mempunyai kebebasan mutlak dalam hubungannya dengan masyarakat. Sementara John Dewey manusia adalah pribadi sebagai wakil dari masyarakat. Demikian pula John McMurray manusia adalah pelaku dan bukan pemikir. ${ }^{4}$

Karl Jasper menyebut manusia sebagai existenzphilosophie yaitu mahluk yang unik serba meliputi, terbuka, punya potensi tetapi juga berbahaya juga bagi dunia, ia adalah makhluk yang paling menarik di dunia. ${ }^{5}$ Menurut Muthahhari manusia mempunyai karakter yang khas. Pada satu sisi mempunyai karakter yang khas. Pada satu sisi mempunyai kecendrungan untuk menuju kebenaran-kebenaran wujud Suci yaitu Allah, tetapi juga mempunyai kecendrungan menjelajah tempat-tempat di luar lingkungannya. Karena itu yang membedakan manusia dengan lainnya adalah iman dan ilmu. Pemisahan antara keduanya akan menurunkan martabat manusia. Iman tanpa ilmu menyebabkan fanatisme, kemunduran, kebodohan. Sebaliknya ilmu tanpa iman mengakibatkan kerakusan, kepongahan, ambisi, perbudakan, penipuan dan kecurangan. ${ }^{6}$ Dari pandangan-pandangan di atas dapat disimpulkan bahwa manusia, adalah mahluk yang berkepribadian (individu) bagian dari masyarakat dan mempunyai kebebasan. Dalam konsepsi Islam manusia diposisikan sebagai makhluk theormorfis yaitu; makhluk yang berkepribadian (individu) bagian dari masyarakat dan mempunyai kebebasan.

Dalam konsepsi Islam manusia diposisikan sebagai makhluk theomorfis yaitu; makhluk dengan potensi yang dimiliki serta usaha yang dilakukannya dapat menyerupai sifat-sifat ke-Tuhanan. Kegiatan moral, spiritual dan keduniaan manusia semuanya harus diintegrasikan dan dipadukan untuk direfleksikan satu sama lainnya. Islam memberikan suatu perspektif kepastian kepada manusia yaitu yang ditanam dan ditumbuhkan melalui pengembangan rasa pribadi yang tak lain merupakan sumber kekuatan bagi dirinya. Ditegaskan Muhammad Iqbal bahwa; "Cita etika Islam ialah membebaskan manusia dari rasa takut dan memberikan kepadanya suatu rasa kepribadian agar ia dapat menyadari bahwa ia adalah suatu sumber kekuatan. ${ }^{7}$ Namun, walaupun manusia mempunyai kebebasan,

4 Dikutip dalam Muhammad dan Fauroni R. Lukman. Visi Al-Qur'an Tentang Etika dan Bisnis. (Jakarta : Salemba Diniyah, 2002), hlm. 92. Lihat, P. Hardono Hadi, Jati Diri Manusia Berdasar Filsafat Organisme Whitehead. (Yogyakarta Kanisius, 1996), hlm. 32-37.

5 Dikutip dalam Muhammad dan Fauroni R. Lukman. Ibid. hlm, 92. Jalaluddin Rakhmat, "Pengantar" dalam buku Murtadha Muthahhari, Perspektif al-Qur'an tentang Manusia dan Agama, (Bandung: Mizan, 1990), hlm. 27.

6 Dikutip dalam Muhammad dan Fauroni R. Lukman. Ibid. hlm. 93. Murtadha Muthahhari, ibid, hlm. 30.

7 Dikutip dalam M. Dawam Rahardjo “Sekapur sirih Tentang Aksiologi Ekonomi Islam”. Kata Pengantar 
bukan dalam pengertian bahwa nilai tertinggi yang dimiliki manusia tidak dapat ditawar dan individu tidak bertanggung jawab kepada masyarakat atas tindakan-tindakannya sejauh tidak menyangkut dirinya dan tidak pada orang lain. ${ }^{8}$ Demikian pula kebebasan yang dimilikinya bukan kebebasan mutlak. Manusia walaupun memiliki kebebasan ia juga memiliki hal-hal yang membatasi kebebasannya, seperti heriditas, lingkungan alam dan sosial, sejarah dan faktor-faktor temporal. Walaupun demikian manusia dapat membebaskan kendala-kendala tersebut dengan kearifan dan ilmu pada satu sisi serta kuasa dan kehendak atau keyakinan pada sisi lain.

Manusia baik secara teologis maupun sosial diamanati oleh Allah untuk kelangsungan hidupnya, agar sesuai dengan apa yang digariskan oleh Allah. Amanah sendiri yang dalam pengertian sehari-hari dipahami sebagai kepercayaan, ternyata memiliki kandungan bobot yang dalam dan merupakan salah satu kunci dalam konsep syari'ah, khususnya dalam kaitannya dengan aspek muamalah yaitu aspek yang menyangkut hubungan antara manusia dan manusia dalam pergaulan masyarakat, ${ }^{9}$ dalam ilmu ekonomi, istilah trust, lebih kurang berarti amanah, walaupun sudah berkembang menjadi beberapa pengertian khusus misalnya lembaga yang mengurusi harta kekayaan untuk kepentingan dan keuntungan pemiliknya dengan kepercayaan atau mempercayakan sesuatu pada orang lain. ${ }^{10}$

Dalam bidang ekonomi dan bisnis amanah merupakan niat atau itikad yang perlu diperhatikan, baik dalam mengelola sumber-sumber alam dan manusia secara makro, maupun dalam mengemudikan suatu perusahaan. Seorang manajer pada dasarnya adalah pemegang amanah. Ia adalah pengelola faktor-faktor produksi yang harus dijalankan berdasarkan amanah dari berbagai pihak, agar tidak terjadi ketidakseimbangan dan kerugian. ${ }^{11}$ Pada dasarnya hidup manusia adalah pengalaman bersama; bahkan dalam unsur-unsurnya yang individual sekalipun merupakan kehidupan bersama dan tingkah laku manusia di dalam strukturnya yang asasi selalu muncul pada pribadi lain. Dengan kata lain manusia adalah anak masyarakat ${ }^{12}$ yang harus bertanggung jawab atas amal perbuatannya. Dengan demikian setiap orang harus memiliki pertanggung jawaban dalam pengertian bahwa etika mengikat dirinya, merasa bertanggung jawab (terhadap baik buruknya suatu masyarakat), ia harus tanpa mundur untuk mengejar kebenaran secara terus-menerus yang disertai oleh keterbukaan untuk menerima kebenaran yang menyakitkan. ${ }^{13}$

Bisnis tidak terlepas dari etika dikarenakan pertama, bisnis tidak bebas nilai. Kedua, bisnis merupakan bagian dari sistem sosial. Ketiga, aplikasi etika bisnis identik dengan pengelolaan bisnis secara professional. ${ }^{14}$ Perkembangan bisnis atau perusahaan, baik sebagai akibat maupun sebagai salah satu sebab perkembangan politik, ekonomi sosial maupun teknologi serta aspek lingkungan di sekitarnya, jika selama ia berinteraksi dan menghasilkan barang dan jasa bagi masyarakat yang membutuhkannya, maka bisnis atau perusahaan itu harus menyadari akan tanggung jawab terhadap lingkungannya, khususnya tanggung jawab sosial dengan segala aspeknya. Agar suatu perusahaan atau bisnis dapat mencapai tujuannya secara kontinyu dengan dukungan masyarakat luas, maka manajemen perusahaan dan konsumen dan stakeholder-nya dengan cara-cara yang berdasarkan nilainilai dan norma-norma etika bisnis. Pada hakikatnya etika merupakan bagian integral dalam bisnis yang dijalankan secara professional. Dalam jangka panjang, suatu bisnis akan tetap berkesinambungan dan secara terus-menerus benar-benar menghasilkan keuntungan, jika dilakukan atas dasar kepercayaan dan kejujuran. Demikian pula suatu bisnis dalam perusahaan akan berlangsung bila bisnis itu dilakukan dengan member perhatian kepada

untuk buku terjemahan karya Syed Nawab Haidar Naqvi, Ethict and Economic: An Islamic Synthesis, hlm. 14-15.

8 Hal ini seperti dianut oleh Jhon Stuart Mill, walaupun ia menambahkan bahwa jika suatu tindakan merugikan masyarakat maka bisa dikenakan sanksi oleh masyarakat tersebut, Lihat P. Hardono Hadi, op.cit, hlm. 113.

9 HM. Quraish Shihab, “Etika Bisnis dalam al-Qur'an”, Jurnal Ulumul Qur'an No 3 VII/1997, hlm. 6.

10 Ibid, hlm. 191.

11 Ibid, hlm. 207.

12 P.Hardono Hadi, op.cit, hlm. 117.

13 Mochtar Lubis, dalam “pengantar” buku, Raymond Aron, Kebebasan dan Martabat Manusia, pent. Rahayu

S Hidayat dkk, (Jakarta: Yayasan Obor Indonesia, 1993), hlm. Vi.

14 Ibid, hlm. 24-25. 
semua pihak dalam perusahaan (stake holders-approach). Inilah sebagian dari tujuan etika bisnis yaitu, agar semua orang terlibat dalam bisnis itu sendiri dan agar belajar bagaimana mengadakan pertimbangan yang baik secara etis maupun ekonomis. ${ }^{15}$ Dari pandangan demikian maka, menjadi suatu keharusan agar suatu bisnis atau perusahaan yang ingin berlanjut dan berkesinambungan dalam proses dan meraih keuntungannya, selalu berupaya memberlakukan pilihan jika tidak etis maka akan tertinggal dan jika etis maka tidak akan tertinggal pula. Untuk melihat relevansi dan implementasi etika bisnis dalam dunia bisnis secara berurutan tersebut akan dipaparkan mengenai Tanggung jawab sosial perusahaan dan Good Corporate Governance.

\section{Tanggung Jawab Sosial Perusahaan Dan Good Corporate Governance (Gcg).}

Tanggung jawab sosial perusahaan merupakan tema yang terus berkembang dalam dunia bisnis. Dalam konteks perusahaan terdapat tiga pandangan mengenai tanggung jawab sosial perusahaan. Pertama, para manajer secara jujur memfokuskan bagi kepentingan perusahaan. Dengan demikian ia merupakan agen untuk mencapai kesejahteraan stakeholders perusahaan. Kedua, para manajer memiliki tugas untuk menyeimbangkan kepentingan pokok dari para pelaku perusahaan. Ketiga, para manajer bertanggung jawab dalam melayani masyarakat, yakni dengan program-program sosial yang menguntungkan masyarakat. ${ }^{16}$ Dari ketiga pandangan di atas, tokoh seperti Milton Friedman memaknai tanggung jawab sosial perusahaan pada pandangan pertama dan kedua. Ia beralasan bahwa tanggung jawab sosial perusahaan bertujuan untuk memperbaiki citra dari kegiatan mencari untung. Pandangan ini merupakan kelanjutan dari pandangan bahwa bisnis tidak perlu mewujudkan tujuantujuan lain dari pada tujuan ekonomi. ${ }^{17}$ Bila pemahaman tentang tanggung jawab sosial perusahaan dipahami seperti demikian, maka dapat dibayangkan bagaimanakah akibatakibat yang ditimbulkan oleh kebijakan-kebijakan suatu perusahaan terhadap lingkungan sosial sekitarnya.

Tanggung jawab sosial perusahaan adalah tanggung jawab moral perusahaan terhadap masyarakat. Tanggung jawab ini dapat diarahkan mulai kepada dirinya sendiri, kepada karyawan, kepada perusahaan lain, kepada lingkungan sosial bahkan sampai kepada Negara. Untuk melihat secara jelas tentang tanggung jawab sosial perusahaan ini harus dibedakan antara tanggung jawab ekonomis dan tanggung jawab sosial. Tanggung jawab ekonomis biasanya diukur dengan keberhasilan kinerja perusahaan dan laba yang didapat. Tetapi tanggung jawab ini tidak bisa terpisah misalnya dalam perusahaan-perusahaan milik pemerintah, seperti perusahaan umum Kereta Api, walaupun dari sisi ekonomis selalu rugi, tetapi karena alasan tanggung jawab sosial perusahaan ini tetap dipertahankan. Dari pandangan ini maka dapat ditarik benang merah sementara bahwa tanggung jawab sosial berada di luar tanggung jawab ekonomi sebuah perusahaan.

Tanggung jawab itu sendiri merupakan suatu prinsip dinamis yang berhubungan dengan keseluruhan perilaku manusia dalam hubungannya dengan masyarakat ataupun institusi. Suatu tanggung jawab bahkan memiliki kekuatan dinamis untuk mempertahankan kualitas keseimbangan dalam masyarakat. ${ }^{18}$ Dalam hubungannya dengan tanggung jawab sosial suatu perusahaan, aksioma tanggung jawab dijabarkan menjadi suatu pola perilaku perusahaan tertentu. Suatu tanggung jawab untuk memperbaiki kualitas lingkungan sosial misalnya menyebabkan perilaku perusahaan tidak sepenuhnya bergantung kepada penghasilannya

15 Franz Magnis Suseno, Berfilsafat dalam Kontek, (Jakarta: PT. Gramedia Pustaka Utama, 1992) hlm. 156162.

16 Goerge A. Steiner and Jhon F. Steiner,Business, Government and Society A Managerial Perspektif, (Singapure: Mc Graw Book Co, 1994), hlm. 109.

17 K. Bertens, op.cit, hlm. 292-294.

18 Dalam hal ini Naqvi berbeda dengan Muhammad Iqbal yang mendasarkan kekuatan dinamis Islam kepada konsep ijtihad. Ijtihad menurut Iqbal merupakan prinsip gerakan dalam struktur ekonomi dan hokum. Lihat, Muhammad Iqbal, Membangun Kembali Pikiran Agama dan Islam. Pent.Ali Sarana untuk memulihkan keseimbangan dalam bidang intelektual di samping jihad. Karena itu, menurut Naqvi, tanggung jawab inilah yang merupakan kekuatan dinamis yang utama dalam Islam. Lihat, Naqvi, op.cit, hlm. 87 terutama bagian foot notenya. 
sendiri, melainkan bergantung pada faktor-faktor lainnya. Dari konsepsi tanggung jawab itu, maka ia memiliki sifat berlapis ganda dan terfokus baik pada tingkat mikro (individual) maupun tingkat makro (organisasi dan sosial), yang kedua-duanya harus dilakukan secara bersama-sama ${ }^{19}$ secara seimbang dalam segala bentuk dan ruang lingkupnya. Antara pemilik, manajer, karyawan, masyarakat dan sosial bahkan dengan negara.

Dalam kenyataannya, ketika kita menyimak sejarah Industri misalnya terdapat beberapa perusahaan besar dan memperoleh nama baik bukan semata-mata karena bisnis tetapi apa yang disebut karya amal. ${ }^{20}$ Karya amal inilah yang justru dapat membangun suatu citra di kalangan masyarakat secara mendalam. Hal ini membuktikan bahwa bagusnya kinerja sebuah perusahaan bukan hanya dibuktikan dengan kinerja mekanis dalam menghasilkan suatu komoditas produk yang berkualitas semata, melainkan, berhubungan erat dengan karya-karya amal yang diberikan kepada masyarakat secara riil sebagai implementasi dari tanggung jawab sosial perusahaannya pada satu sisi dan berakibat pada memperkokoh suatu citra positif pada sisi lainnya. Dengan demikian karya-karya amal dalam lingkup yang luas tidak bertentangan tujuan ekonomis jangka panjang suatu bisnis, sebaliknya sangat mendukung. Lebih jauh pertanggung jawaban sosial perusahaan secara luas terkait erat dengan tuntutan pembangunan pemerintahan yang bersih atau juga yang disebut Clean Goverment atau Good Corporate Governance $(G C G)$. Dalam hubungan ini etika bisnis memberikan tuntunan agar dalam proses produksi yang berkesinambungan untuk memperoleh tujuan ekonomis, tidak melalaikan hukum yang telah ditetapkan sebagai proteksi tidak terjadinya penyelewengan wewenang dan kekuasaan pemerintah dalam hubungannya dengan upaya meningkatkan pendapatan GNP misalnya. Sebaliknya juga aparatur pemerintahan tidak melakukan kemungkinan-kemungkinan dalam hubungannya dengan para pengusaha suatu kejahatan yang terstruktur yang hanya ditujukan bagi kepentingan segelintir pihak saja.

Dalam era reformasi, tuntutan terhadap etika bisnis dan implementasi Good Corporate Governance, telah menjadi semacam paradigma baru, dengan menuntut unsur-unsur misalnya, tuntutan adanya transparasi dalam kepengurusan dan pemerintahan yang baik di segala sektornya. Tuntutan efisiensi di segala bidang. Tuntutan tanggung jawab kepengurusan (responsibility and accountability) di segala bidang. Tuntutan kewajaran (fairness) dalam menjalankan aktivitas usaha. Dan tuntutan profesionalisme. ${ }^{21}$ Dengan tuntutan-tuntutan di atas diharapkan pelaksanaan sistem dan proses baik dalam perusahaan maupun pemerintahan dan hubungan keduanya dilakukan secara terbuka dan tidak memberikan peluang sedikitpun bagi munculnya praktek-praktek korupsi, kolusi dan nepotisme. ${ }^{22}$

\section{Argumentasi Yang Mendukung Dan Menentang Prinsip Tanggung Jawab.}

Persoalan tanggung jawab sosial dalam dunia bisnis merupakan salah satu tema yang kerapkali diperdebatkan. Para pendukung prinsip tanggung jawab sosial menyatakan bahwa karena sebuah bisnis merupakan sumber penyebab berbagai persoalan seperti misalnya polusi, maka harus melaksanakan prinsip tersebut. Sementara para penentangnya menyatakan bahwa sebuah usaha, dengan cara membuat keuntungan dan membaginya kepada masyarakat dalam bentuk upah dan pajak, sebenarnya telah membayar kewajiban mereka dan tidak harus dibebani dengan tanggung jawab sosial terhadap berbagai persoalan yang memang tidak dapat sepenuhnya dihindari.

Mereka mendukung diterapkannya prinsip tanggung jawab sosial menyatakan bahwa pada batas-batas tertentu dimana sebuah usaha memahami hakekat persoalan yang mereka ciptakan, maka lebih baik bila mereka berusaha memecahkan persoalan tersebut. Tidak seperti halnya pemerintah yang secara finansial sangat terikat, maka sebuah usaha dapat menyisihkan sebagian persoalan yang mereka hadapi. Para penentang prinsip tanggung

19 Rafik Issa Beekun, op.cit, hlm. 27.

20 Contoh yang konkrit adalah Carnegie yang banyak membantu lembaga pendidikan dari 2800 perpustakaan, selain itu Biil Gate termasuk juga dalam pembangunan teknologi informasi pada lembaga-lembaga pendidikan dan sosial. Lihat, K. Bertens, ibid, hlm. 299-302.

21 Hadori, ibid, hlm. 5.

22 Muhammad dan Fauroni R. Lukman. 2002. Visi Al-Qur'an Tentang Etika dan Bisnis. Jakarta : Salemba Diniyah. hlm. 114-118. 
jawab sosial mencemooh besarnya kekuasaan yang diperoleh berbagai perusahaan sekali mereka telah berhasil menyelesaikan sebuah masalah sosial. Karena besarnya kontribusi keuangan mereka, berbagai alat tipu daya iklan demi kepentingan memperbesar keuntungan mereka. Semua perusahaan harus bersikap proaktif berkaitan dengan persoalan tanggung jawab sosial. Seperti halnya mereka mampu tampil sebagai pakar-pakar strategi kepercayaan dalam mengembangkan keuntungan kompetitif di pasar, mereka perlu mengembangkan sejumlah piranti untuk meningkatkan peran tanggung jawab sosial mereka. Sejumlah piranti ini dalam beberapa hal dapat dinyatakan secara eksplisit sementara yang lain secara implisit. 23

Mengenai moral, dalam pandangan sosialistis, manusia tampak terikat pada beban tanggung jawab kolektif yang berlebihan, hingga menghancurkan kebebasan manusia. Di lain pihak, titik berat Islam pada Kehendak Bebas, membebaskan manusia dari cengkraman determinisme sejarah. Dalam pandangan Islam, determinisme sejarah tidak lepas dari keinginan manusia yang lewat kekuatan tak dapat dibendung, dapat mengubah jalannya sejarah. Islam menyetimbangkan keinginan bebas dengan pertanggung jawaban, dan meletakkannya dalam pandangan keseluruhan yang menerima bahwa manusia dilahirkan bebas. Dengan demikian, ia menolak kekerasan tak wajar dalam kerja. (QS. Al-Maidah : 6).“Allah tidak hendak menyulitkan kamu, tetapi Dia hendak membersihkan kamu dan menyempurnakan nikmat-Nya bagimu, supaya kamu bersyukur".

Implikasinya adalah jaminan kemerdekaan bagi individu dalam menghadapi penyalahgunaan kekuasaan ekonomi, sosial atau fisik oleh orang-orang yang memilikinya. Keadilan sosial ini juga berlaku atas semua bagian masyarakat dengan pertanggung jawaban yang disertai kebebasan. Karenanya menurut konsepsi keadialan sosial Islam ini untuk membantu menjelmakan Tauhid dalam kehidupan, maka ilmu ekonomi dipadukan dengan ilmu etika. Keadilan sosial, pendidikan universal, pertumbuhan ekonomi dan employment maksimum merupakan sasaran-sasaran kebijaksanaan pokok suatu perekonomian Islami. Keadilan Sosial menuntut pembasmian ketimpangan-ketimpangan pendapatan dan kemakmuran yang tidak ekonomis dan tak bermoral. Proses ini akan banyak diperkuat oleh penciptaan kesempatan-kesempatan kerja baru di kalangan kelompok-kelompok pendapatan lebih rendah. Selanjutnya, ada kebutuhan mutlak akan pendidikan universal, yang secara umum akan menentukan mutu keadilan sosial. Akan tetapi, keadilan sosial harus dipertahankan tidak hanya untuk satu masa tertentu saja, melainkan juga secara dinamik. Hal ini dengan tepat mendefenisikan sasaran pertumbuhan ekonomi dalam suatu perekonomian Islami. Pandangan Islam mengenai pertumbuhan dikondisikan oleh dua pertimbangan yang saling berkaitan :

a. Tuntutan umum Islami untuk menjamin dan mengamankan pendistribusian pendapatan (kemakmuran) secara adil, kini menetapkan batas atas dalam tingkat pertumbuhan yang layak.

b. Perlunya mempertahankan equity antar generasi, menetapkan suatu batas atas bagi banyaknya sumber yang kini dapat didistribusikan. Oleh karena itu, dari penggunaan saat ini kita harus menyisihkan cukup banyak sumber untuk pembentukan modal. Akan tetapi, pembentukan modal dalam suatu perekonomian Islam akan harus secara jelas melingkupi pembentukan modal manusia, yang karenanya menekankan adanya pendidikan, yang diperhitungkan sebagai satu investasi . Pendidikan bebas universal akan membentuk manusia mewujudkan potensi anugerah Ilahinya, dalam kondisi yang cocok, pendidikan akan menggerakkan mesin penyeimbang-penyeimbang yang berdaya raksasa.

Beberapa pendekatan yang diperlukan untuk memenuhi diktum-diktum keadilan sosial ini haruslah jelas, mengingat bahwa untuk sebagian besar penduduk, bekerja hanyalah satu-satunya cara untuk memperoleh pendapatan. Memang benar bahwa para penganggur akan dibayar oleh baitu-maal (dana kesejahteraan sosial). Tapi, ini saja belum cukup, karena

23 Muhammad dan Fauroni R. Lukman. 2002, Visi Al-Qur'an Tentang Etika dan Bisnis, Jakarta : Salemba Diniyah, hlm. 194-197. 
kerja bukan hanya merupakan sumber pendapatan, melainkan juga merupakan atribut bagi kehormatan diri, yang berusaha ditanamkan oleh Islam kepada kaum Muslimin. Selanjutnya, suatu dana jaminan sosial yang semakin meningkat akan harus dibelanjai dengan pemajakan tambahan. Jelaslah bahwa pendekatan yang lebih baik adalah dengan membelanjai pendidikan tambahan untuk pada akhirnya memungkinkan adanya kesempatan kerja. Hal pokok yang harus dipahami adalah bahwa mutu luar biasa dari suatu perekonomian Islami adalah Kesetimbangan, yang harus ditegakkan kembali dengan cara yang sistematis, sadar dan secara ekonomis dapat diwujudkan, untuk menjamin agar kesatuan kehidupan tetap efektif, agar kemerdekaan manusia yang hanya dikendalai oleh pertanggung jawaban sosial untuk mewujudkan cita-cita Islami demi terciptanya suatu tatanan sosial yang dinamis dan adil tidak terganggu gugat.

\section{Pandangan Islam Mengenai Tanggung Jawab Sosial Perusahaan Dan Karyawan.}

Etika bisnis menurut ajaran Islam digali langsung dari Al-Qur'an dan Hadist Nabi. Dalam ajaran Islam, etika bisnis dalam Islam menekankan pada empat hal, yaitu: Kesatuan (unity), Keseimbangan (equilibrium), Kebebasan (Free will), dan tanggungjawab (responsibility). ${ }^{24}$ Ada empat pilar etika manajemen binis menurut Islam seperti yang dicontohkan Nabi Muhammad SAW. Pertama, "Tauhid" yang berarti memandang bahwa segala asset dari transaksi bisnis yang terjadi di dunia adalah milik Allah, manusia hanya mendapatkan amanah untuk mengelolanya. Kedua, "Adil", artinya segala keputusan menyangkut transaksi dengan lawan bisnis atau kesepakatan kerja harus dilandasi dengan "akad saling setuju" dengan sistem propit and lost sharing. Pilar ketiga adalah "Kehendak Bebas". Manajemen Islam mempersilahkan umatnya untuk menumpahkan kreativitas dalam melakukan transaksi bisnis sepanjang memenuhi asas hukum ekonomi Islam, yaitu halal. Dan keempat adalah "Pertanggung jawaban". Semua keputusan seorang pimpinan harus dipertanggungjawabkan oleh yang bersangkutan. ${ }^{25}$

Tanggung jawab sosial merujuk pada "kewajiban-kewajiban sebuah organisasi untuk melindungi dan memberi kontribusi kepada masyarakat dimana ia berada". ${ }^{26}$ Sebuah organisasi mengemban tanggung jawab sosial dalam tiga domain: pada pelaku organisasi, pada lingkungan alam, dan pada kesejahteraan sosial secara umum. Segala kebebasan dalam melakukan segala aktivitas bisnis oleh manusia maka manusia tidak lepas dari pertanggungjawaban yang harus diberikan dengan Wasilah Al-Hayat yang dikuasakan oleh Allah kepada manusia ini bukanlah kepemilikian yang sesungguhnya secara hakiki, namun manusia dengan segala fasilitas dan sarana kehidupan yang dimiliki secara amanah ini hanya sekedar diserahi amanah untuk mengelola secara benar sesuai yang diberikan petunjuk-petunjuk (Manhaj Al-Hayat) oleh Allah di dalam Al-Qur'an dan sunnah Nabi. Sudah tentu manusia yang sudah dititipi amanah dalam mengelola sumber daya ini harus mempertanggungjawabkan kepada Allah sebagai pemilik yang sebenarnya baik di dunia maupun di akherat kelak.

Kebebasan yang dimiliki manusia dalam menggunakan potensi sumber daya mesti memiliki batas-batas tertentu, dan tidak dipergunakan sebebas-bebasnya tanpa batas, melainkan dibatasi oleh koridor hukum, norma dan etika (Manhaj Al-Hayat) yang tertuang di dalam Al-Qur'an dan Sunnah Rasul yang harus dipatuhi dan dijadikan referensi atau acuan dan landasan dalam menggunakan potensi sumber daya yang dikuasai. Tidak kemudian digunakan untuk melakukan kegiatan bisnis yang terlarang atau diharamkan, seperti judi, kegiatan produksi yang merugikan masyarakat, melakukan kegiatan riba dll. Yang jelasjelas dilarang oleh Al-Qur'an dan Sunnah. Apabila digunakan untuk melakukan kegiatan

24 Mubyarto(2002): Etika, Agama dan Sistem Ekonomi. Jurnal Ekonomi Rakyat, Tahun 1 Nomor 2, April 2002.

25 Rudito Bambang dan Famiola MeliA, 2007, Etika Bisnis \& Tanggung jawab Sosial Perusahaan di Indonesia, Bandung: Rekayasa Sain, hlm. 59.

26 Jay B. Barney \& Ricky W. Griffin, The Management of Organizations, USA : Houghton Miffin Company, 1992, hlm. 726. 
bisnis yang jelas-jelas halal, maka cara pengelolaan yang dilakukan harus juga dilakukan dengan cara-cara yang benar, adil dan mendatangkan manfaat optimal bagi semua komponen masyarakat yang secara kontributif ikut mendukung dan terlibat dalam kegiatan bisnis yang dilakukan.

Berbagai persoalan etis mewarnai hubungan antara pekerja dengan perusahaan, terutama berkaitan dengan persoalan kejujuran, kerahasiaan, dan konflik kepentingan. Dengan demikian, seorang pekerja tidak boleh menggelapkan uang perusahaan, dan juga tidak etis lain terjadi ketika para manajer menambahkan harga palsu untuk makanan dan pelayanan lain dalam pembukuan keuangan perusahaan mereka. Beberapa dari mereka melakukan penipuan karena merasa dibayar rendah, dan ingin mendapatkan upah yang adil. Pada saat yang lain, hal ini dilakukan semata karena ketamakan. Sebagai contoh, Albert Miano yang menggelapkan uang 1 juta dolar dari para pekerjanya mengakui bahwa faktor pendorong utamanya adalah ketamakan. ${ }^{27}$ Bagi para pekerja muslim, Allah SWT memberikan peringatan yang jelas dalam al-Qur'an : (QS. Al-A'raf (7): 33). Pekerja Muslim, yang menyadari makna ayat di atas, seharusnya tidak berbuat sesuatu dengan cara-cara yang tidak etis. Niat yang baik seringkali tergelincir oleh situasi yang ambigu (bermakna ganda) dan jebakan-jebakan yang jelas. Tindakan yang salah jika kita menyamakan pegawai di pemerintahan dengan buruh di perusahaan swasta, menyamakan gaji yang memenuhi kebutuhan pegawai di pemerintahan dengan gaji di perusahaan swasta. Jika buruh mengajukan permintaan yang berlebihan kepada majikan, maka itu suatu kezaliman. Kadang-kadang, buruh itu berproduksi rendah, kurang berpengalaman, dan kurang terampil, lebih lagi bila memiliki keluarga besar, orang tua lanjut usia, saudara yang masih belia, keturunan yang lemah dan istri lebih dari seorang, maka dosa apakah yang telah diperbuat majikan sehingga ia harus menanggung semua beban ini? Para pemilik perusahaan wajib memberikan gaji sesuai dengan keahlian kerja. Gaji bisa meningkat dengan bertambahnya umur pekerja dan meningkatnya pengalaman, juga ketika harga barang di pasaran melonjak, dan perusahaan mendapatkan laba yang meningkat. ${ }^{28}$

Manusia diberi kebebasan untuk memiliki harta, berlomba mendapatkannya, dan membelanjakannya. Ia pun berhak menyimpan, menyumbang, dan mewariskan hartanya untuk anaknya. Dengan kebebasan yang diberikan itu, sehingga menjadi mahluk yang pantas menjadi khalifah Allah dan pemakmur bumi. ${ }^{29}$ Di samping tanggung jawab bisnis terhadap orang di lingkungannya dengan mengikutsertakan mereka sebagai pekerja, dengan tidak sangat membatasi jumlah pekerja karena takut biaya tenaga kerja terlalu tinggi, maka bisnis juga memiliki tanggung jawab sosial lainnya. Dunia bisnis hidup di tengah-tengah masyarakat. Kehidupannya tidak bisa lepas dari kehidupan masyarakat. Oleh sebab itu ada suatu tanggung jawab sosial yang dipikul oleh bisnis banyak kritik dilancarkan oleh masyarakat terhadap bisnis, yang kurang memperhatikan lingkungan.

Banyak timbul perbedaan pendapat mengenai hal ini, ada yang mengatakan bahwa tanggung jawab bisnis hanya terbatas sampai menghasilkan barang dan jasa buat konsumen dengan harga yang murah. Ada yang mengatakan tanggung jawab bisnis ialah jangan mengambil keuntungan besar, tetapi yang wajar sajalah. Ada pendapat bahwa bisnis harus turut mengatasi masalah yang terjadi di masyarakat, tanpa memperhatikan apakah bisnis secara langsung ataupun tidak langsung menimbulkan masalah itu. Jika kita perhatikan tanggung jawab sosial dari bisnis terhadap masyarakat akan dipengaruhi oleh :

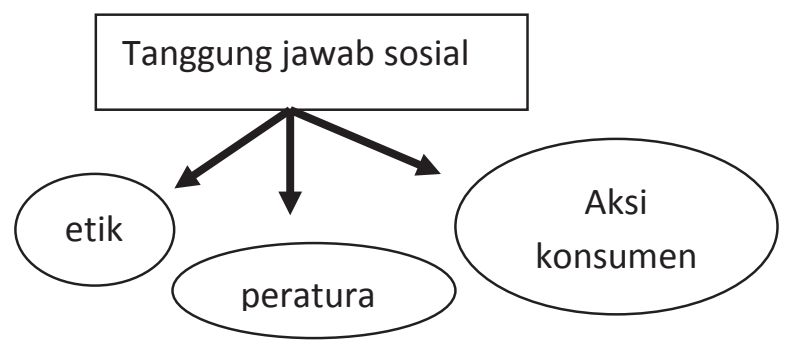

27 Fortune, April 25, 1998.

28 Yusuf Qardhawi, 1997, Norma dan Etika Ekonomi Islam, Jakarta : GEMA INSANI, hlm. 234.

29 Yusuf, Ibid, hlm, 209. 
Etik berasal dari perasaan kebenaran yang ada pada tiap-tiap hati sanubari manusia. Sedangkan peraturan berasal dari pemerintah atau masyarakat. Aksi konsumen terjadi karena ketidakpuasan yang sudah berlarut-larut dan menginginkan adanya suatu perbaikan, dan menimbulkan gerakan konsumerisme, ataupun gerakan umum di masyarakat. Pada mulanya tanggung jawab bisnis ialah hanya untuk menghasilkan laba bagi para pemilik. Kemudian muncul aksi yang menghendaki agar bisnis juga bertanggung jawab menghasilkan dan menjual barang yang bermutu bagi masyarakat. ${ }^{30}$

\section{Merumuskan Pekerjaan Dan Tanggung Jawab Yang Jelas Untuk Penempatan Dan Pemberian Sangsi Dan Reward.}

Pimpinan Perusahaan harus mengetahui batas kewenangan dan yang dimiliki oleh karyawannya. Hal ini penting untuk memperoleh kejelasan dalam melakukan kegiatan yang dilakukan oleh masing-masing pihak atau pekerjaan yang jelas-jelas menjadi tanggung jawabnya masing-masing. Oleh karena, itu setiap pekerjaan perlu dirumuskan keterangan dan penjelasan mengenai apa dan bagaimana serta seberapa jauh kewenangan itu skup dan batasbatasnya. Hal ini dengan harapan bahwa hubungan industrial yang terjadi antara pimpinan dan bawahan dan antara bawahan dan bawahan di dalam suatu keseluruhan pekerjaan tim menjadi jernih dan tidak cenderung menjadi overlap antara karyawan dan pimpinan dan antara sesama karyawan. Aturlah pekerjaan masing-masing pekerja atau karyawan supaya pekerjaan yang dilakukan oleh seluruh karyawan menjadi lancar tak terhambat oleh persepsi berbeda antar karyawan tentang masing-masing fungsi secara jelas tentang pekerjaan mereka masing-masing. Hal lain yang penting dalam manajemen sumber daya manusia adalah proses penempatan. Berikanlah pekerjaan pada pihak yang kompeten sesuai dengan keahlian dan keterampilan orang. Memberikan tanggung jawab pada mereka yang berhak dan kompeten sesuai dengan keahlian dan kecakapan adalah sangat sesuai dengan ajaran Islam. Hal ini seperti yang dinyatakan dalam surat An-Nisa :58

Keberlanjutan dalam bidang ekonomi, lingkungan dan sosial dapat dilakukan oleh korporasi yang mempunyai kebudayaan perusahaan sebagai suatu bentuk tanggung jawab sosial perusahaan (Corporate Social Responsibility). Corporate Social Responsibility dapat dipahami sebagai kontribusi untuk peningkatan kualitas hidup dari karyawan dan keluarganya, komunitas lokal dan komunitas secara lebih luas. Pengertian ini sama dengan apa yang telah ditelorkan oleh The World Business Council for Sustainable Development (WBCSD) yaitu komitmen bisnis untuk berkontribusi dalam pembangunan ekonomi berkelanjutan, bekerja dengan para karyawan perusahaan, keluarga karyawan tersebut, berikut komunitas-komunitas setempat (lokal) dan komunitas secara keseluruhan, dalam rangka meningkatkan kualitas kehidupan. Secara umum Corporate Social Responsibility merupakan peningkatan kualitas kehidupan mempunyai arti adanya kemampuan manusia sebagai individu anggota komunitas untuk dapat menanggapi keadaan sosial yang ada, dan dapat menikmati serta memanfaatkan lingkungan hidup termasuk perubahan-perubahan yang ada sekaligus memelihara. Atau untuk memproduksi dampak positif pada komunitas. Atau dapat dikatakan sebagai proses penting dalam pengaturan biaya yang dikeluarkan dan keuntungan kegiatan bisnis dari stakeholder baik secara internal (pekerja, stakeholders dan penanam modal) maupun eksternal (kelembagaan pengaturan umum, anggota-anggota komunitas, kelompok komunitas sipil dan perusahaan lain). Dengan demikian, tanggung jawab perusahaan secara sosial tidak hanya terbatas pada konsep pemberian donor saja, tapi konsepnya sangat luas dan tidak bersifat statis dan pasif, hanya dikeluarkan dari perusahaan, akan tetapi hak dan kewajiban yang dimiliki bersama antar stakeholders. Konsep Corporate Social Responsibility melibatkan tanggung jawab kemitraan antara pemerintah, lembaga sumberdaya komunitas, juga komunitas setempat (lokal). Kemitraan ini, tidaklah bersifat pasif dan statis. Kemitraan ini merupakan tanggung jawab bersama secara sosial antar

30 Alma, Buchari, 2007, Dasar-dasar Etika Bisnis Islami, Bandung : CV. Alfabeta : Anggota IKAPI Jawa Barat, hlm. 234-236. 
stakeholders. Konsep kedermawanan perusahaan (corporate philanthropy) dalam tanggung jawab sosial tidak lagi memadai, karena konsep tersebut tidak melibatkan kemitraan tanggung jawab perusahaan secara sosial dengan stakeholder lainnya. ${ }^{31}$

\section{PENUTUP}

Tanggung jawab merupakan hal terpenting dalam pemenuhan kualifikasi bagi sebuah perusahaan, sebagai bentuk kepedulian dan respon yang positif terhadap pertumbuhan suatu usaha yang dijalankan. Untuk menjaga keberlangsungan sebuah aktifitas perusahaan, maka sudah selayaknya para pengusaha dengan kesadaran penuh memperhatikan tanggung jawab yang diemban sesuai dengan perintah Tuhan sebagai kode etik bisnis. Tanggung jawab sosial perusahaan menjadi landasan bagi para stakeholders untuk mempertahankan bisnis sampai waktu yang tidak ditentukan.

Sedangkan untuk para karyawan sendiri memahami pekerjaannya sebagai seorang karyawan dan tidak meminta lebih banyak dari pada haknya yang disesuaikan dengan kemampuan atau keahlian dimilikinya. Untuk itu para karyawan selayaknya memberikan loyalitasnya kepada perusahaan yang sudah memberikan kepercayaan dan fasilitas bagi para karyawan untuk berinovasi dalam kemampuan atau keahlian yang dimilikinya.

Dalam Islam sendiri sangat menjunjung tinggi akan tanggung jawab sosial baik itu untuk perusahaan dan para karyawan. Dalam al-Qur'an juga dijelaskan bahwa setiap kita (manusia) akan diminta pertanggung jawaban kelak di akhirat atas apa yang telah diperbuat selama di dunia ini, begitu juga dalam sebuah hadits yang mengatakan bahwa setiap orang yang diberikan beban tanggung jawab haruslah sesuai dengan keahlian yang dimiliki dan menjunjung tinggi tanggung jawab kepada perusahaan yang telah memberikan kepercayaan bagi para karyawannya dalam menjalankan bisnis.

\section{DAFTAR PUSTAKA}

Alma, Buchari. 2007. Dasar-dasar Etika Bisnis Islami. Bandung : CV. Alfabeta : Anggota IKAPI Jawa Barat.

Jay B. Barney \& Ricky W. Griffin, 1992, The Management of Organizations, USA : Houghton Miffin Company.

Muhammad dan Fauroni R. Lukman. 2002. Visi Al-Qur'an Tentang Etika dan Bisnis. Jakarta : Salemba Diniyah.

Muslich. 2004. Etika Bisnis Islami : Landasan Filosofis, Normatif dan Substansi Implementatif. Yogyakarta : EKONISIA.

Rudito Bambang dan Famiola Melia. 2007. Etika Bisnis \& Tanggung jawab Sosial Perusahaan di Indonesia, Bandung: Rekayasa Sains.

Qardhawi, Yusuf. 1997. Norma dan Etika Ekonomi Islam, Jakarta : GEMA INSANI.

Rahardjo M. Darmawan, Sekapur sirih Tentang Aksiologi Ekonomi Islam, Kata Pengantar untuk buku terjemahan karya Syed Nawab Haidar Naqvi, Ethict and Economic: An Islamic Synthesis.

Shihab, M. Quraish, 1996, Tafsir Maodlu'I atas berbagai persoalan umat, Bandung: Mizan. , Etika Bisnis dalam al-Qur'an, Jurnal Ulumul Qur'an No 3 VII/1997.

Franz Magnis Suseno, 1992, Berfilsafat dalam Kontek, Jakarta: PT. Gramedia Pustaka Utama.

31 Rudito Bambang dan Famiola Melia, 2007, Etika Bisnis \& Tanggung jawab Sosial Perusahaan di Indonesia, Bandung: Rekayasa Sains, hlm. 207-208. 
Steiner, Goerge and Steiner, 1994, Jhon F.,Business, Government and Society A Managerial Perspektif, Singapure: Mc Graw Book Co.

Muhammad dan Fauroni R. Lukman. 2002. Visi Al-Qur'an Tentang Etika dan Bisnis. Jakarta : Salemba Diniyah.

Al-Majallah, Seria No. 2556, Referensi, Al-Majallah (Ottoman Courts Manual [Hanafi]), 1324.

Rudito, Bambang dan Famiola, Melia, 2007, Etika Bisnis \& Tanggung jawab Sosial Perusahaan di Indonesia, Bandung: Rekayasa Sain. 